\title{
PENGARUH INTERVENSI PEMBERIAN PENYULUHAN ASI EKSKLUSIF PADA IBU HAMIL TRIMESTER III TERHADAP PEMBERIAN ASI EKSKLUSIF DI DAERAH PERKOTAAN KABUPATEN LEBAK TAHUN 2012
}

\author{
Omo Sutomo*, Kadar Kuswandi*
}

\begin{abstract}
Abstrak
Bayi merupakan mahluk Tuhan yang memerlukan perlindungan, perawatan dan nutrisi yang memadai selama kurun waktu yang ditentukan. Diperlukan pemahaman berupa pengetahuan dan keinginan yang kuat dari ibu dan anggota keluarga lain untuk memungkinkan memberikan air susu ibu (ASI) pada tahun-tahun awal kelahiran bayi yakni sedidaknya sampai bayi berumur enam bulan. Kenyataan dilapangan menujukkan bahwa masih ditemukan bayi yang tidak cukup mendapatkan asupan berupa pemberian ASI sampai bayi berusia enam bulan. Penelitian bertujuan untuk memperoleh informasi tentang pengaruh intervensi pemberian penyuluhan tentang ASI ekslusif pada ibu hamil trimester III terhadap pemberian ASI eklusif pada bayi di daerah perkotaan kabupaten Lebak tahun 2012. Penelitian ini merupakan penelitian analitik dengan desain kuasi eksperimen. Yang menjadi populasi ialah seluruh ibu trimester III akhir, dengan jumlah sampel 165 orang. Penelitian akan dilakukan di daerah perkotaan kabupaten Lebak. Analisis data dilakukan secara bertahap yakni analisis univariat, analisis bivarait. Hipotesa peneltian ini ialah pemberian penyuluhan tentang ASI eksklusif pada ibu hamil trimester III berpengaruh terhadap pemberian ASI ekslusif pada bayi di daerah perkotaan kabupaten Lebak. Hasil penelitian menunjukkan bahwa rata rata lamanya pemberian ASI Eksklusif lebih lama $(69,19$ hari) pada ibu menyusui yang diberi penyuluhan lebih atau sama dengan tiga kali, bila dibandingkan yang diberi penyuluhan kurang atau sama dengan dua kali, hanya memiliki rata-rata pemberian ASI Eksklusif selama 42,45 hari. Dengan nilai $\mathrm{p}=0,000$, dan nilai OR sebesar 3,386. Hasil penelitian ini diharapkan bermanfaat sebagai bahan masukan untuk perencanaan bidang kesehatan khususnya untuk penguatan promosi kesehatan dan perilaku ibu dalam pemberian ASI eklusif di daerah perkotaan khususnya di kabupaten Lebak.
\end{abstract}

Kata Kunci: Asi Ekslusif, Trimester III

*Poltekkes Kemenkes Banten

\section{Pendahuluan}

Pembangunan kesehatan diarahkan

untuk meningkatkan kesadaran, kemauan dan kemampuan hidup sehat bagi setiap orang agar peningkatan derajat kesehatan masyarakat setinggi- tingginya dapat terwujud. Pembangunan kesehatan diselenggarakan dengan berdasarkan pada kemanuasian, pemberdayaan dan kemandirian, adil dan merata, serta pengutamaan dan manfaat 
dengan perhatian khusus pada penduduk rentan, antara lain ibu, bayi, anak, lanjut usia (lansia), dan keluarga miskin. Salah satu upaya pembangunan kesehatan dilaksanakan melalui peningkatan pemberdayaan masyarakat, dengan penekanan pada peningkatan perilaku dan kemandirian masyarakat serta upaya promotif dan preventif. (Kemenkes, 2010).

Beberapa hasil yang telah dicapai dalam pembangunan kesehatan sebagaimana didapatkan dari hasil evaluasi rentra Kementrian Kesehatan 2005-2009, menunjukkan capaian, misalnya oleh program perbaikan gizi masyarakat, menunjukkan hasil antara lain pemberian kapsul vitamin A pada anak balita usia 6-59 bulan sebesar $85 \%$ melampaui target $80 \%$, dan pemberian tablet besi (Fe) pada ibu hamil sebesar $75 \%$ dari target $80 \%$. (Kemenkes, 2010). Hasil Riskesda menunjukkan terjadi perbaikan gizi anak balita. Namun demikian keadaan perbaikan keadaan ini belum menyentuh masalah yang berkaitan dengan masih tingginya bayi yang lahir dengan berat badan lahir rendah (BBLR) sebesar 11,5\%, dan tingginya prevalence anak balita yang pendek (stanting) akibat kekurangan gizi dalam jangka waktu lama (kronis) yaitu 36,8\% (Riskesda, 2007). Demikian pula masalah yang berkaitan dengan perilaku pemberian air susu ibu secara ekslusif (ASI ekslusif) pada bayi usia 0-6 bulan justru mengalami penurunan, dari 39,4\% pada tahun 2003 menjadi $32 \%$ pada tahun 2007 dari target 80\%. (Kemenkes, 2010 \& Bapenas, 2009)

Kondisi ini tentu perlu mendapat perhatian, karena itu Kemenkes (2010), memprogramkan bahwa kedepan perbaikan gizi, termasuk nutrisi bagi bayi melalui pemberian ASI eklusif perlu difokuskan pada kelompok ibu hamil dan anak sampai usia 2 tahun, mengingat dampaknya terhadap pertumbuhan fisik, kecerdasan, dan produktifitas generasi yang akan datang.

Pemberian ASi ekslusif kepada bayi merupakan perilaku kesehatan yang berkaitan dengan aktifitas ibu dalam memberikan ASI pada bayi. Perilaku kesehatan sebagaimana dijelaskan Green (1980), ditentukan oleh 3 faktor utama, yaitu : 1) predisposing factors (factorfaktor pemudah), meliputi pengetahuan, sikap, keyakinan, nilai-nilai, dan demografi; 2) enabling factors (faktor- 
faktor pemungkin), meliputi ketersediaan sumberdaya kesehatan, keterjangkauan sumberdaya kesehatan, prioritas dan komitmen masyarakat/pemerintah terhadap kesehatan, keterampilan yang berkaitan dengan kesehatan, dan factor ke 3) reinforcing factors (factor-faktor penguat) merupakan factor penyerta (yang datang sesudah) perilaku memberikan ganjaran, insentif, atau hukuman atas perilaku dan berperan bagi menetap atau lenyapnya perilaku itu. Penguat dapat diwujudkan dari sikap dan perilaku keluarga, teman sebaya, guru, majikan, dan petugas kesehatan.

\section{Metode Penelitian}

Penelitian ini merupakan penelitian analitik disain kuasi eksperimen dengan pendekatan cross sectional. Populasi penelitian ini adalah seluruh ibu hamil trimester III akhir, dengan jumlah sampel sebanyak 165 orang ibu hamil.

Seluruh sampel diukur dengan ditanyakan jumlah mendapat penyuluhan dari bidan desa tentang ASI Eksklusif selama hamil trimester III akhir, dan kemudian ditanyakan pula. tentang lamanya menyusui secara eksklusif pada bayinya.

\section{Hasil Penelitian}

\begin{tabular}{|c|c|c|c|c|}
\hline Frek & $\begin{array}{l}\text { nsi Penyuluha } \\
\text { Di Wilayah }\end{array}$ & $\begin{array}{l}\text { Tabel } 1 \\
\text { \& Lama F } \\
\text { tkotaan K } \\
\text { Tahun } 201\end{array}$ & $\begin{array}{l}\text { nberian AS } \\
\text { upaten Leba }\end{array}$ & kslusif \\
\hline \multirow[t]{2}{*}{$\mathrm{NO}$} & \multirow{2}{*}{$\begin{array}{c}\text { Uraian } \\
\text { Kegiatan }\end{array}$} & \multicolumn{2}{|c|}{ Frek / Lama } & \multirow{2}{*}{$\begin{array}{l}\text { Rata- } \\
\text { Rata }\end{array}$} \\
\hline & & Minimal & Maksimal & \\
\hline 1 & $\begin{array}{l}\text { Frek. } \\
\text { Pnylhn yg } \\
\text { Dilakukan }\end{array}$ & 0 kali & 4 kali & 2 kali \\
\hline 2 & $\begin{array}{l}\text { Lama } \\
\text { Pemberian } \\
\text { Asi Ekslusif }\end{array}$ & 0 hari & 120 hari & $\begin{array}{c}57 \\
\text { hari }\end{array}$ \\
\hline
\end{tabular}

Tabel 1 menunjukkan bahwa frekuensi penyuluhan yang dilakukan oleh petugas dan lamanya pemberian asi ekslusif yang dilakukan oleh ibu pada bayinya sangat bervariasi, dengan ratarata penyuluhan sebanyak dua kali, sedangkan rata-rata lama pemberian asi ekslusif selama lima puluh tujuh hari.

Tabel 2

Rata-Rata Lamanya Pemberian Asi Ekslusif Berdasarkan Frekuensi Penyuluhan Pada Ibu Menyusui di Wilayah Perkotaan Kabupaten Lebak Tahun 2012

\begin{tabular}{lccc}
\hline $\begin{array}{c}\text { Frekuensi } \\
\text { Penyuluhan }\end{array}$ & $\begin{array}{c}\text { Rata-Rata } \\
\text { Lamanya } \\
\text { Pemberian } \\
\text { Asi Ekslusif }\end{array}$ & $\begin{array}{c}\text { Rata-Rata } \\
\text { Keseluruhan }\end{array}$ & $\begin{array}{c}\text { Nilai } \\
\mathrm{p}\end{array}$ \\
\hline $\begin{array}{l}\text { Kurang atau } \\
\text { sama dgn 2 } \\
\text { kali }\end{array}$ & 42,45 hari & & \\
\hline $\begin{array}{l}\text { Lebih atau } \\
\text { sama dgn } 3 \\
\text { kali }\end{array}$ & 69,19 hari & & \\
\hline
\end{tabular}

Tabel 2 menunjukkan bahwa penyuluhan yang dilakukan sebanyak 
tiga kali atau lebih memiliki rata-rata lama pemberian asi ekslusif lebih lama (69,19 hari) bila dibandingkan dengan penyuluhan yang dilakukan dua kali atau kurang, hanya memiliki rata-rata lama pemberian asi eksklusif 42,45 hari; dengan rata-rata pemeberian asi ekslusif secara keseluruhan selama 57,06 hari. Sedangkan nila p yang diperoleh sebesar 0,000 .

Tabel 3

Distribusi Ibu Menyusui Berdasarkan Frek. Penyuluhan Dan Lamanya Pemberian Asi Ekslusif

Di Wilayah Perkotaan Kabupaten Lebak Tahun 2012

\begin{tabular}{|c|c|c|c|c|c|}
\hline \multirow{2}{*}{$\begin{array}{l}\text { Frek. } \\
\text { Pnylhn }\end{array}$} & \multicolumn{2}{|c|}{ Lama Asi Ekslusif } & \multirow{2}{*}{ Total } & \multirow{2}{*}{$\begin{array}{c}\text { Nilai } \\
\mathrm{p}\end{array}$} & \multirow{2}{*}{ OR } \\
\hline & $<90 \mathrm{Hr}$ & $90 \mathrm{Hr}$ & & & \\
\hline$\leq 2$ & $\begin{array}{c}46 \\
(59,0 \%)\end{array}$ & $\begin{array}{c}32 \\
(41,0 \%)\end{array}$ & $\begin{array}{c}78 \\
(100,0 \\
\%)\end{array}$ & & \\
\hline$\geq 3$ & $\begin{array}{c}28 \\
(29,8 \%)\end{array}$ & $\begin{array}{c}66 \\
(70,2 \%)\end{array}$ & $\begin{array}{c}94 \\
(100,0 \\
\%)\end{array}$ & 0,000 & $\begin{array}{l}3,386 \\
(1,802- \\
6,372)\end{array}$ \\
\hline Total & $\begin{array}{c}74 \\
(43,0 \%)\end{array}$ & $\begin{array}{c}98 \\
(57,0 \%)\end{array}$ & $\begin{array}{c}172 \\
(100,0 \\
\%)\end{array}$ & & \\
\hline
\end{tabular}

Secara deskriptif tabel 3 menunjukkan bahwa kelompok ibu yang menyusui secara ekslusif kurang dari 90 hari (3 bulan) lebih banyak terjadi $(59,0 \%)$ pada ibu yang diberi penyuluhan kurang atau sama dengan dua kali selama kehamilannya, bila dibandingkan dengan kelompok ibu yang diberi penyuluhan sebanyak tiga kali atau lebih, hanya $29,8 \%$ yang menyusui secara ekslusif kurang dari 90 hari. Disamping itu table 3 juga menunjukkan bahwa masih banyak bayi $(43,0 \%)$ yang tidak diberikan asi secara eksklusif (< 90 hari). Secara bivariat diperoleh nilai $\mathrm{p}$ sebesar 0,000 , dengan nilai OR sebesar 3,386.

\section{Pembahasan}

Pemberian Asi Eksklusif pada bayi sampai usia 6 (enam) bulan merupakan salah satu upaya yang sangat baik untuk mendapatkan hasil tumbuh dan berkembangnya bayi secara optimal, sehingga bayi dapat mencapai kemampuannya sesuai dengan bertambahnya usia. Disamping itu, melalui pemberian asi eksklusif, bayi dapat memiliki daya tahan tubuh yang lebih baik, sehingga bayi menjadi tidak mudah sakit yang tentunya berdampak pada pertumbuhan dan perkembangan yang optimal.

Pernyataan tersebut sesuai dengan yang dinyatakan oleh Heildenberg (2008) bahwa bayi manusia yang diberi susu sapi, yang disebut juga susu formula, cenderung mudah jatuh sakit; hal itu diakibatkan karena proporsi zat gizi yang terkandung di dalamnya tidak sempurna atau tidak sesuai dengan yang 
dibutuhkan oleh bayi. Sebaliknya Heildenberg (2008) juga menyatakan bahwa ASI bias membantu melindungi bayi melawan beberapa infeksi umum yang menyebabkan diare dan muntahmuntah, juga infeksi-infeksi di dalam telinga, hidung, sinus, dan paru-paru. ASI juga dapat melindungi bayi dari alergi karena konsumsi protein. Di sisi lain, ASI dapat menunjang terhadap perkembangan bayi; bayi yang diberi ASI cenderung cepat belajar dari pada bayi-bayi yang diberi susu botol, dan bayi yang diberi ASI memiliki kecenderungan lebih cerdas atau memiliki IQ yang lebih tinggi bila dibandingkan dengan bayi yang diberi susu botol.

Melihat besarnya manfaat ASI untuk pertumbuhan dan perkembangan bayi, maka perlu kiranya ada upaya penyadaran tentang pentingnya ASI (terutama ASI eksklusif) yang terus menerus dilakukan oleh petugas kesehatan kepada ibu-ibu sejak mereka hamil, yang harapannya nanti para ibu menjadi lebih mengerti dan siap untuk memberikan ASI nya pada bayi mereka, sehingga bayi mereka (dalam jangka panjang) dapat menjadi generasi yang sehat dan cerdas sehingga mampu bersaing dalam era persaingan pasar bebas. Dengan demikian generasi mendatang dapat berperan secara optimal dalam membangun bangsa ini, yang pada akhirnya dapat mengangkat nama baik bangsa.

Akan tetapi kenyataan menunjukkan bahwa dari hasil penelitian yang dilakukan di wilayah perkotaan Kabupaten Lebak, diperoleh rata-rata mereka menyusui bayinya secara eksklusif hanya mencapai 57 (lima puluh tujuh) hari saja atau kurang dari dua bulan. Hal itu menunjukkan bahwa masih rendahnya kesadaran para ibu dalam memberikan ASI secara eksklusif pada bayinya; yang semua itu dapat disebabkan karena ketidakmengertian para ibu terhadap pentingnya menyusui bayi secara eksklusif.

Sedangkan bila dilihat dari perbedaan rata-rata lamanya menyusui secara eksklusif berdasarkan frekuensi penyuluhan yang diberikan oleh petugas kesehatan, maka hasilnya menunjukan bahwa ibu yang diberi penyuluhan tentang asi eksklusif kurang atau sama dengan dua kali selama kehamilannya, mereka memiliki rata-rata lamanya 
memberikan asi eksklusif selama 42,25 hari, dan bagi ibu-ibu yang diberi penyuluhan tentang asi eksklusif sebanyak tiga kali atau lebih, memiliki rata-rata lama pemberian asi eksklusif 69,19 hari; dengan nilai p sebesar 0,000, yang mengartikan bahwa frekuensi atau banyaknya pemberian penyuluhan tentang asi eksklusif pada ibu, memberikan pengaruh yang signifikan terhadap lamanya pemberian asi eksklusif.

Hasil itu sejalan dengan hasil analisis bivariat yang masing-masing variable (frekuensi penyuluhan dengan lamanya pemberian asi eksklusif) dikategorikan. Dari hasil analisis itu menunjukkan bahwa proporsi menyusui eksklusif yang kurang dari 90 hari atau tiga bulan lebih banyak terjadi $(59,0 \%)$ pada ibu yang memperoleh penyuluhan tentang asi eksklusif kurang atau sama dengan dua kali, bila dibandingkan dengan kelompok ibu yang memperoleh penyuluhan tiga kali atau lebih, hanya 29,8\% yang menyusui eksklusif kurang dari 90 hari atau tiga bulan; dan bila dilihat dari nilai $\mathrm{p}$ yang diperoleh sebesar 0,000 , yang berarti terdapat hubungan bermakna antara frekuensi penyuluhan tentang asi eskklusif pada ibu dengan lamanya pemberian asi eksklusif yang dilakukan oleh ibu pada bayinya.Seangkan nilai OR yang diperoleh sebesar 3,388, yang berarti bahwa ibu yang memperoleh penyuluhan sedikit (kurang atau sama dengan dua kali) tentang asi eksklusif selama kehamilannya, memiliki risiko tiga kali lebih besar untuk menyusui bayinya kurang dari 90 hari (3 bulan) bila dibandingkan dengan kelompok ibu yang memperoleh penyuluhan tentang asi eksklusif lebih atau sama dengan tiga kali (banyak) selama kehamilannya.

Semua hasil penelitian itu menunjukkan bahwa frekuensi penyuluhan tentang asi eksklusif yang dilakukan oleh petugas kesehatan selama ibu melalui proses kehamilannya memiliki dampak positif berupa semakin meningkatnya lama masa menyusui bayi secara eksklusif pada bayinya. Kenyataan itu memberikan fakta bahwa penyuluhan merupakan factor yang harus dipertimbangkan dalam upaya mengubah perilaku seseorang; dengan diberi penyuluhan yang lebih intensif, maka seseorang akan menjadi lebih mengerti dan memahami untuk bertindak 
sesuai yang diharapkan dari isi penyuluhan bersangkutan.

Ahmadi (1998) menyatakan bahwa individu dapat menyadari atau memahami sesuatu apabila individu tersebut menangkap adanya objek yang diamati, memiliki alat indra yang baik, dan adanya perhatian. Pernyataan itu menggambarkan bahwa penyuluhan sebagai objek yang diamati oleh ibu hamil akan masuk ke dalam benak ibu hamil melalui alat pengindraan (pendengaran dan penglihatan yang baik), dimana pada saat diberi penyuluhan ibu hamil tersebut memiliki perhatian yang baik terhadap penyampaian penyuluhan yang dilakukan oleh petugas kesehatan, sehingga ibu dapat memahami pentingnya pemberian asi eksklusif pada bayinya, yang kemudian ibu mempraktekkannya berupa pemberian asi eksklusif pada bayinya. Dan semakin sering ibu menerima atau mengamati objek tersebut (penyuluhan), maka ibu akan semakin lebih faham dan mengerti, sehingga mereka menjadi lebih siap untuk mempraktekkannya pada saat bayinya lahir.
Notoatmodjo (2003) menyatakan bahwa perilaku dan gejala perilaku yang tampak pada kegiatan organism dipengaruhi oleh factor genetic (keturunan) dan lingkungan. Secara umum dapat dikatakan bahwa genetic dan lingkungan merupakan penentu dari perilaku makhluk hidup termasuk perilaku manusia. Keturunan merupakan konsepsi dasar atau modal untuk perkembangan perilaku makhluk hidup itu untuk selanjutnya. Sedangkan lingkungan merupakan kondisi untuk perkembangan perilaku tersebut. Suatu mekanisme penggabungan dari kedua factor tersebut dalam rangka terbentuknya perilaku disebut proses belajar. Karena itulah maka pendidikan kesehatan, khususnya tentang pemberian atau pentingnya asi eksklusif perlu dilakukan oleh bidan, terutama pada saat melakukan pemeriksaan kehamilan maupun pada saat melakukan kunjungan rumah dengan tujuan dapat mengubah perilaku ibu hamil maupun ibu menyusui, sehingga mereka dapat mempersiapkan diri serta mempraktekkannya dalam memberikan asi eksklusif pada bayinya. Selain itu, Notoatmodjo (2003) juga menyatakan 
bahwa pendidikan kesehatan merupakan upaya tersendiri untuk menunjang keberhasilan program kesehatan yang sedang atau akan dijalankan; melalui pendidikan kesehatan, seseorang dapat mendapatkan informasi tentang cara hidup sehat, sehingga dalam jangka waktu tertentu mereka dapat menunjukkan perilakunya sesuai dengan yang diharapkan (kesehatan).

Dengan demikian, melalui pendidikan kesehatan atau penyuluhan kesehatan tentang pemberian asi eksklusif pada ibu-ibu hamil yang dilakukan oleh tenaga kesehatan, maka ibu-ibu hamil tersebut dapat memperoleh keterangan atau informasi yang benar tentang pentingnya pemberian asi eksklusif pada bayi mereka yang akan dilahirkan. Melalui pemahaman tersebut, maka ibu hamil dapat mempersiapkan diri supaya mereka benar-benar dapat menyusui bayinya secara eksklusif; persiapan-persiapan tersebut dapat berupa mengkonsumsi makanan yang dapat memacu pengeluaran asi secara optimal, atau upaya lain berupa penyiapan atau perawatan payudara ibu, sehingga secara fisik benar-benar siap untuk menyusui.
Di sisi lain Purwanto (1999) dan Suparjo (2004) menyatakan bahwa lingkungan sangat besar pengaruhnya terhadap individu. Dengan adanya lingkungan, maka individu dapat menerima pengaruh atau dipengaruhi oleh lingkungan. Dari pernyataan itu dapat dijelaskan bahwa tenaga kesehatan dengan materi penyuluhannya tentang asi eksklusif dapat diartikan sebagai suatu yang berada di sekitar ibu hamil yang dapat berpengaruh terhadap perilaku ibu hamil melalui peningkatan pemahamannya tentang asi eksklusif, sehingga ibu dapat mengarahkan perilakunya pada kesiapan untuk menyusui secara eksklusif dan kemudian mereka praktekkan pada saat bayinya telah lahir.

Oleh karena itu, untuk meningkatkan pengetahuan ibu hamil khususnya tentang pentingnya asi eksklusif dapat dilakukan melalui pendidikan yang bersifat non formal seperti penyuluhan atau upaya pendidikan lainnya yang dapat dilakukan di masyarakat, sehingga ibu hamil khususnya, dan umumnya keluarga dan masyarakat dapat meningkat / bertambah pengetahuannya dalam bidang 
kesehatan. Yulius K. Nyerere dalam Ka Badan PPSDM Depkes (2007) menyatakan bahwa tujuan pendidikan dan pembangunan pada dasarnya adalah untuk pembebasan manusia dari kebodohan, ketergantungan dan pengekangan; sedangkan pembangunan adalah untuk pengembangan manusia, bukan sebaliknya yang menekankan pada pengembangan materi atau fisik. Pembangunan harus terus dijalankan agar mereka yang secara ekonomi lemah tidak semakin terpinggirkan. Demikian pula mereka yang kaya atau kuat ekonominya mau peduli dengan yang miskin.

\section{Simpulan}

a. Masih banyak ditemukan ibu yang memberikan ASI secara tidak eksklusif pada bayinya.

b. Rata-rata lamanya pemberian ASI Eksklusif masih dibawah jumlah hari yang diharapkan.

c. Frekuensi penyuluhan tentang ASI Eksklusif yang diberikan oleh petugas kesehatan kepada ibu selama dalam kehamilan, berpengaruh secara signifikan terhadap lamanya pemberian ASI
Eksklusif pada bayi yang dilahirkannya.

d. Ibu yang diberi penyuluhan tentang ASI Eksklusif kurang atau sama dengan 2 kali berisiko tiga kali lebih besar untuk tidak memberikan ASI secara eksklusif pada bayinya bila dibandingkan dengan ibu yang diberi penyuluhan 3 kali atau lebih.

\section{Daftar Pustaka}

Ahmadi, Abu (1998). Psikologi Umum. Cetakan kedua. Jakarta: Rineka Cipta.

Dinas Kesehatan Lebak (2011). Profil Kesehatan Kabupaten Lebak Tahun 2010. Lebak: Dinkes Lebak

Green L.W (1980). Health Educational Planning A Diagnostic Approach. First edition. California: Mayfield Publishing Company

Heildenberg, Steven (2008). Diterjemahkan oleh Khotibul Umam. Buku Pintar Perawatan Bayi - Panduan Ibu Menangani Bayi dalam Masalah Tidur, Makan, Higienis, Menangis, dan lain-lain. Cetakan pertama. Jakarta: Prestasi Pustaka.

Kemenkes RI (2010). Rencana Strategi Kementrian Kesehatan Tahun 2010-2014. Jakarta: Kemenkes RI.

Kementrian Negara Perencanaan Pembangunan Nasional / Badan Perencanaan Pembangunan 
Nasional (2009). Pembangunan Kesehatan dan Gizi di Indonesia: Overview dan Arah ke Depan Background Study RPUJMN 20102014. Jakarta: Bapenas

Kepala Badan PPSDM Depkes RI. 2007. Majalah Pengembangan dan Pemberdayaan SDM Kesehatan: Ketika Bidan Harus Siaga. Vol. 3, No. 3. Jakarta: Badan PPSDM Depkes RI

Notoatmodjo, Soekidjo et al. 2001. Pendidikan - Promosi Dan Perilaku Kesehatan (Teori dan Aplikasi) KMP - 600. Jakarta: FKM - UI.

Notoatmodjo, Soekidjo. 2003. Ilmu Kesehatan Masyarakat: PrinsipPrinsip Dasar. Cetakan kedua. Jakarta: Rineka Cipta

Purwanto, Heri (1999). Pengantar Perilaku Manusia Untuk Keperawatan. Cetakan I. Jakarta: EGC

Soetjiningsih (1997). ASI: Petunjuk Praktis Untuk Tenaga Kesehatan. Jakarta: EGC

Suparjo, Ariaguna. 2004. Ilmu Perilaku dan Faktor yang Mempengaruhinya. Jakarta: Grafika Buana. 